\title{
SAFETY PROBLEMS OF SMALL WATER SUPPLY SYSTEMS
}

\section{PROBLEMY BEZPIECZEŃSTWA MALYCH WODOCIĄGÓW}

\section{Barbara Tchórzewska-Cieślak, Katarzyna Pietrucha-Urbanik, Dawid Szpak}

\author{
Politechnika Rzeszowska im. Ignacego Łukasiewicza \\ cbarbara@prz.edu.pl,kpiet@prz.edu.pl,dsz@prz.edu.pl
}

\begin{abstract}
The paper presents issues related to risks associated with the operation of small water supply systems on the background of water consumer safety assessment made on the basis of risk analysis. Definition of water consumer safety loss as a risk associated with the water consumption of poor quality or water lack was proposed. For this purpose, a three-parameter matrix is implemented with the parameters of the probability of a representative accident scenario, the losses of the water consumers and their protection. Risk management, together with the implementation of protective barriers of small water supply system against threats is a fundamental condition for the continued operation of the system.
\end{abstract}

Keywords: water supply infrastructure, consumers safety, risk analysis

Streszczenie: $W$ pracy przedstawiono zagadnienia zagrożeń związanych zfunkcjonowaniem matych systemów zaopatrzenia $w$ wodę na tle oceny bezpieczeństwa konsumentów wody wykonanej na podstawie analizy ryzyka. Zaproponowano definicje miary utraty bezpieczeństwa konsumentów wody do spożycia jako ryzyko zwiazane z możliwościa spożycia wody złej jakości lub jej brakiem. W tym celu zaimplementowano matrycę trójparametryczna z parametrami prawdopodobieństwa wystapienia reprezentatywnego scenariusza awaryjnego, skutkami dla konsumentów wody oraz z ich ochrona. Zarzadzanie ryzykiem, wraz zimplementacja barier ochronnych matych systemów wodociagowych przed zagrożeniami jest podstawowym warunkiem ciagłości funkcjonowania systemu.

Stowa kluczowe: infrastruktura wodociagowa, bezpieczeństwo konsumentów, analiza ryzyka 
Safety problems of small water supply systems

Problemy bezpieczeństwa małych wodociagów

\section{SAFETY PROBLEMS OF SMALL WATER SUPPLY SYSTEMS}

\section{Introduction}

Safety is a concept referring to a lack of threat, guarantees liquidation or minimization of risks. With regard to consumers of drinking water, it is understood as the probability of avoiding risks resulting from the water consumption of incompatible quality with the current regulations or the water lack $[2,5,6,11,16$, $23,28]$. The measure of such a perceived safety is a risk of water supply system (WSS) functioning system of collective water supply. Water intake for rural settlement units usually is underground water. These are the water of better quality than surface water and do not require complex treatment processes [16]. In many cases underground water are subjected to serious pollution, often difficult to remove, which is a serious threat to water consumers. The threats of the groundwater purity often are the result of area pollution related to agricultural activity (chemical fertilizers, pesticides, etc.), as well as the contamination of aquifer layer from the sewage, as a result of not having sewer system by settlement unit $[4,5]$. The cause of contamination of underground water intakes can also be incidental events such as uncontrolled discharge of untreated sewage from the plant, leaking landfill or spills from manure. Often the cause of the contamination is difficult to be determined. Another problem is secondary water pollution in the water supply system, which major cause are adverse hydraulic conditions of the network (such as low flow rate of water) combined with aging pipelines or chemical instability of water [17-19, 22].

It is estimated that one from ten residents in the European Union use small water supply systems including private wells [28]. According to the classification given by the AWWA small water systems are those in which the water demand is less than 20 thousand $\mathrm{m}^{3}$ per day [25] and in [12] authors classify small water supply as such in which the number of water connections is less than 2500 . The classification based on the number of serviced population occurs in the compilation of World Bank ( $<125000$ serviced residents) [27], and is given by the Environmental Protection Agency of the United States (<3300 serviced residents) [26] and in the Directive Commission of the European Union [3] as the demand of less than 1 thousand $\mathrm{m}^{3} / \mathrm{d}$ of water or system that services less than 5 thousand residents. The specified classifications are differentiated among others through population density and the degree of region development.

The current problem for water supply of small agglomerations is extreme phenomena related to climate change such as floods and droughts. Low water levels cause dry of wells and difficulties in the intake of surface water [1,9]. Most major problem is bad condition of facilities supplying water and irregular distribution of water collection points, eg. near vacuum trucks, what can cause potential contamination [8]. 
An obstacle to the improvement of the existing situation is the lack of financial resources and technical facilities, improper operation of the system, as well as the lack of awareness among consumers of hazard occurring in water [13-15].

The main aim of this work is to present the safety issues of water consumers in rural settlements. The work includes basic concepts of consumer safety and method of safety analysis based on the risks associated with the operation of rural WSS.

\section{Safety of water consumers}

As a result of the occurrence in the WSS all kinds of undesirable events, consumers may do not have access to the water with adequate quality for a few hours, days or even weeks. Examples of disruption in the functioning of the rural water supply are:

- pollution of water intake of pesticide coming from the fertilization of agricultural land (village councils Pikoszów, 01.2012 r.),

- pollution of water intake as a result of flooding (Fences, $04.2008 \mathrm{r}$.),

- prolonged lack of rainfall, high temperatures, hydrological drought, lack of water in wells (gm. Błażowa, 07-08.2015 r.),

- considerable scattered villages, insufficient capacity water supply, lack of investment in the expansion of water supply (Mokra Wieś, 04.2015 r.),

- low water level in the river, hydrological drought (municipality Brzyska, 10.2012 r.), destruction of the water supply pipeline from the well to the water treatment plant (WTP) as a result of the removal of the embankment at the water intake resulting floods (Dąbrówki, 08.2004 r.),

- pollution of water intake by chlorpyrifos (fotoorganic pesticide used to counter potato beetle), (gm. Pikoszów, 11.2011 r.),

- passage of coliform bacteria to the water intake, probably due to prolonged rainfall (Jabłonna, $09.2008 \mathrm{r}$.),

- outpouring of the river near the water treatment plant WTP (Fences, $04.2008 \mathrm{r}$.).

For the analysis of the water consumer safety the concept of the actual safety level (ASL) was introduced, which is defined as the level of protection of consumers of water in the given operating conditions of WSS. The following levels of water consumer safety were distinguished:

- tolerable safety level (TSL) - the level of water consumer safety, in which as a result of the WSS operation there are no reasons for life or health threat of water consumers,

- controlled safety level (CSL) - the level of water consumer safety, which as a result of the WSS operation there may be threat to the water consumer health, but there are sufficient barriers protecting water consumers,

- unacceptable safety level (USL) - the level of water consumer safety, beyond which consumers are exposed to injury or life loss.

On the Figure 1 the procedure of activities related to the operation of small water supply systems in terms of ensuring their safety was presented [10, 19, 22-24]. 
Safety problems of small water supply systems Problemy bezpieczeństwa matych wodociagów

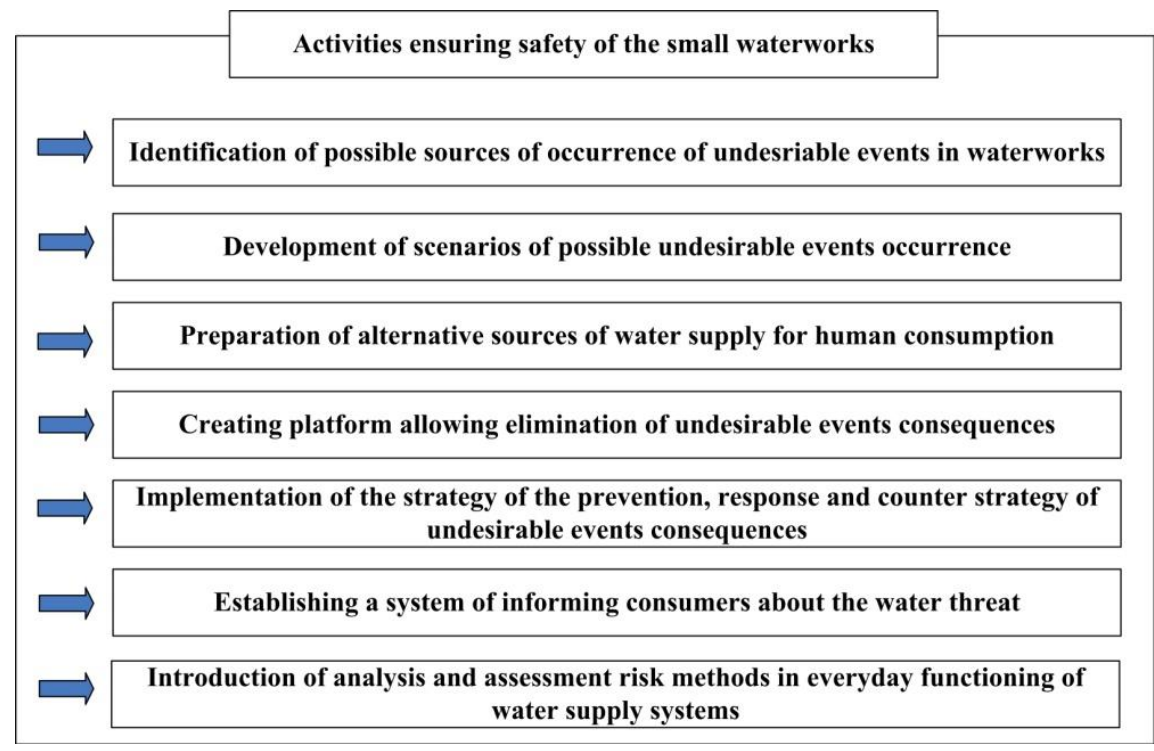

Fig. 1. Activities ensuring the continuity of the small waterworks functioning

In order to analyze the water consumer safety, it is necessary to define its operating states. Therefore the following operating conditions of WSS, taking into account the nominal production capacity of water $\left(Q_{d n}\right)$ and maximum daily water demand during the year $\left(Q_{d \max }\right)$, can be distinguished:

- operational capability state - the WSS state, which is characterized by operation without. The system performs its task in accordance with applicable regulations and expectations of water consumers, in terms of the water amount for consumption, ie. the nominal production of water capacity $Q_{d n} \geq 0,7 Q_{d \max }$ and quality: water for human consumption meets the requirements of the existing Regulation [20]. The public water supply does not cause threat to the life and health of water consumers,

- limited operational capability state - the WSS state, which is characterized by short-term disruptions in the work: $0,3 Q_{d \max } \leq Q_{d n}<0,7 Q_{d \max }$ or there is a lack in the water supply for $24 \mathrm{~h}$, there is the possibility of undesirable events escalation (the so called domino effect). If the water does not cause health risk to consumers, it is possible to exceed the limit values specified in Annexes No. 3 and No. 4 of the Regulation [20]. If the pollutant may be removed within 30 days, the competent sanitary inspector finds water suitability for consumption under the terms of the so-called granted derogation [20],

- loss of operational capability state - the WSS state in which the system operates inefficiently or stops working, $0<Q_{d n}<0,3 Q_{d \max }$ or there is a lack in the water supply for $>24 \mathrm{~h}$. Consumers are exposed to the consumption of water with inadequate quality, 
- emergency state - the WSS state, in which the system stops working, and consumers are deprived of access to drinking water. No protection of consumers from the water threats (eg. as a result of floods, hydrological drought).

\section{Water consumers safety assessment methods on the basis of risk analysis}

As a result of the occurrence in the WSS of the so-called representative emergency scenario (RES), water consumers are exposed to the possibility of safety loss. The measure of loss of water consumer safety is the risk associated with the consumption of poor quality water or water lack [6, 7, 16-19].

The risk is a function of three parameters $r=f(P, C, O)$. Parameters $P$ and $C$ are directly proportional to the risk value and the parameter $O$ is inversely proportional to the risk value [16-19]. The adopted assumption found its justification and is purposeful, due to the inversely proportional character of adopted parameter protection, which has significant impact on risk reduction, including for example the use of an early warning system. The introduction of significant protection can lead to minimize the risk of undesirable events occurrence in water supply systems. This method has been used in the practice of water supply due to the nature of this system, as well as modified is recommended by the WHO in assessing water safety plans (WSPs).

The risk of water consumer $r_{k}$ is determined by the author's method of prof. J. Rak according to the formula [18]:

$$
r_{k}=\frac{P_{S i} \cdot C_{S i}}{O_{S i}}
$$

$P_{S i}$ - the probability of $i^{\text {th }}$ RES occurrence,

$C_{S i}-$ point weight associated with possible consequences for water consumers as a result of the $i^{\text {th }}$ RES occurrence,

$O_{S i}-$ point weight associated with water consumer protection and water against $i^{\text {th }}$ RES.

For each parameter $P_{S i}, C_{S i}$ and $O_{S i}$ levels were assumed on the base of the scale from 1 to 5 using a matrix method in the form of a three-parameter described in detail in $[16,18,19,23]$. Risk has a value in the range [0,20-25]. In Tables 1-3 the adoption of the following scale and weights point for the individual parameters was proposed.

Tabele 1. Criteria and weight point for the parameter $P[19,23]$

\begin{tabular}{|l|l|c|}
\hline Probability & Parameter description $P$ & Point weight \\
\hline very small & once in 10 years or less & 1 \\
\hline small & once in 5-10 years & 2 \\
\hline average & once per 1-5 years & 3 \\
\hline big & 1-12 times a year & 4 \\
\hline very big & more often than once a month & 5 \\
\hline
\end{tabular}


Safety problems of small water supply systems Problemy bezpieczeństwa matych wodociagów

Table 2. Criteria and weight point for the parameter C [19, 21, 23]

\begin{tabular}{|c|c|c|}
\hline 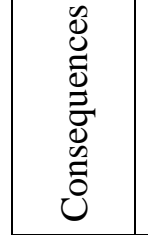 & Parameter description $C$ & $\begin{array}{l}\vec{z} \\
.00 \\
\frac{3}{2} \\
. \overline{0} \\
0\end{array}$ \\
\hline $\begin{array}{l}\text { very } \\
\text { small }\end{array}$ & $\begin{array}{l}\text { minor deterioration of organoleptic parameters of water does not } \\
\text { constitute a threat to consumers, } \\
\text { - local reduction of pressure in the water mains, }\end{array}$ & 1 \\
\hline small & $\begin{array}{l}\text { - significant deterioration of the organoleptic parameters of water } \\
\text { constituting nuisance for consumers, } \\
\text { - no health threat, } \\
\text { - single consumer complaints of water, } \\
\text { - decrease the daily water production to } 70 \% Q_{\operatorname{maxd}} \text { or interruption in } \\
\text { the supply of water for } 2 \text { hours } \\
\text { - lowering the pressure in the water mains, }\end{array}$ & 2 \\
\hline average & $\begin{array}{l}\text { - considerable nuisance organoleptic water (high turbidity, odor), } \\
\text { - exceeding the physicochemical parameters, } \\
\text { - threat to the consumers health, } \\
\text { - } \text { single indisposition of consumers health associated with the } \\
\text { consumption of contaminated water, } \\
\text { - decrease the daily water production to } 0,5 Q_{d \max } \leq Q_{d n}<0,7 Q_{d \max } \\
\text { or local interruptions in water supply from } 2 \text { to } 12 \mathrm{~h}, \\
\text { - lowering the pressure in the water mains, }\end{array}$ & 3 \\
\hline big & $\begin{array}{l}\text { - } \text { exceeding the physico-chemical and bacteriological parameters, } \\
\text { - secondary water pollution in different parts of the water supply } \\
\text { network, } \\
\text { - numerous consumer poisoning associated with the consumption of } \\
\text { contaminated water, } \\
\text { - announcements in the local media informing about pollution of } \\
\text { drinking water, } \\
\text { - decrease daily water production } 0,3 Q_{d \max } \leq Q_{d n}<0,5 Q_{d \max } \text { or local } \\
\text { interruptions in water supply from } 12 \text { to } 24 \mathrm{~h}, \\
\text { - lowering the pressure in the water mains, }\end{array}$ & 4 \\
\hline $\begin{array}{l}\text { very } \\
\text { big }\end{array}$ & $\begin{array}{l}\text { - extensive bacteriological contamination of water, the presence of } \\
\text { pathogenic microorganisms, exceeding the physicochemical } \\
\text { parameters, } \\
-\quad \text { secondary water pollution in the water supply network, } \\
- \text { mass poisoning, hospitalization of injured, } \\
- \text { messages in the national media informing about pollution of } \\
\text { drinking water, } \\
- \text { the need to involve professional emergency services: eg. State Fire } \\
\text { Service, the State of Emergency Medicine, } \\
- \text { decrease of the daily water production values } Q_{d n}<0,3 Q_{d m a x}, \\
- \text { interruptions in the supply of safe water for consumption over } 24 \mathrm{~h} \text {, } \\
- \text { failure of main equipment WTP or pumping water, } \\
- \text { failure of the main water pipes supplying the municipality. }\end{array}$ & 5 \\
\hline
\end{tabular}


Table 3. Criteria and weight point for the parameter $O[19,23]$

\begin{tabular}{|c|c|c|}
\hline Protection & Parameter description $O$ & $\begin{array}{l}\text { Point } \\
\text { weight }\end{array}$ \\
\hline very low & $\begin{array}{l}\text { - monitoring of the raw water and treated water the quality } \\
\text { carried out only in case of a threat, } \\
\text { - lack of alternative treatment technologies, lack of } \\
\text { alternative sources of water, no tanks network, } \\
\text { - lack of monitoring system of water supply network, } \\
\text { - the network in an open system, } \\
\text { - no own services removing the consequences of any } \\
\text { undesirable events, }\end{array}$ & 1 \\
\hline low & $\begin{array}{l}\text { - periodic monitoring raw water and treated water the } \\
\text { quality (once a week, once a month) } \\
\text { - lack of alternative treatment technologies, alternative } \\
\text { sources of water and the water supply netowrk reservoirs, } \\
\text { - lack of monitoring system of water supply network, } \\
\text { - the network in an open system, } \\
\text { - a long time to wait for the intervention of emergency } \\
\text { service in water supply, }\end{array}$ & 2 \\
\hline average & $\begin{array}{l}\text { - standard system of monitoring of raw and treated water } \\
\text { quality, } \\
\text { - lack of alternative treatment technologies, alternative } \\
\text { sources of water and the water supply network reservoirs, } \\
\text { - standard monitoring system of water supply network } \\
\text { functioning, } \\
\text { - the network in an open system, the inability to cut off the } \\
\text { damaged pipe without interruption in water supply, } \\
\text { - a long time to wait for the intervention of emergency } \\
\text { service in water supply, }\end{array}$ & 3 \\
\hline big & $\begin{array}{l}\text { - standard system of monitoring of raw and treated water } \\
\text { quality (sampling water several times a day), } \\
\text { - the lack of an alternative treatment technology, } \\
\text { - the possibility of using alternative sources of water or } \\
\text { water stored in tanks of water supply network, } \\
\text { - standard system of monitoring the work of water supply } \\
\text { network (measurement of pressure and flow rate on the } \\
\text { main water supply facilities) } \\
\text { - the network in a mixed system, }\end{array}$ & 4 \\
\hline very big & $\begin{array}{l}\text { - a comprehensive system for monitoring of raw water and } \\
\text { treated quality with alarm function, } \\
\text { - the possibility of using alternative treatment } \\
\text { technologies, alternative sources of water, the water } \\
\text { stored in tanks of water supply network, } \\
\text { - a comprehensive system for monitoring the work of } \\
\text { water supply network, the use of SCADA and GIS, } \\
\text { - the network in a closed system, the ability to cut off the } \\
\text { damaged pipe, } \\
\text { - reserving strategic objects on WTP or pumping water, } \\
\text { - efficient emergency service in water supply. }\end{array}$ & 5 \\
\hline
\end{tabular}


Safety problems of small water supply systems Problemy bezpieczeństwa małych wodociagów

The safety assessment is based on comparison of the resulting risk values of the adopted scale. In determining criteria for evaluating the water consumer safety, expert approach of risk analysis was presented, taking into account the criterial appropriate risk levels, which were adopted on the basis of the operational data analysis, opinions and information obtained from experts in water companies. In the expert assessment the analysis of similar undesirable events was used.

In Table 4 criteria for assessing the water consumer safety were proposed.

Table 4. Level of water consumer safety

\begin{tabular}{|c|c|}
\hline Established risk & Level of water consumer safety \\
\hline $0,20 \leq r_{T} \leq 5,0$ & TPB \\
\hline $5,0<r_{K} \leq 9,0$ & KPB \\
\hline $9,0<r_{N} \leq 25,0$ & NPB \\
\hline
\end{tabular}

The developed method is shown on the application example:

- in drinking water significant deterioration of organoleptic parameters was reported; $C=2$,

- deterioration of organoleptic parameters of water intended for human consumption is recorded by the water company several times a year; $P=4$,

- water supply system is equipped with a standard system for monitoring water quality, there is the possibility of using alternative sources of water or water stored in tanks of water supply network in the case of crisis situation; $O=4$.

Based on the above information risk value $r=2$ was determined, which on the basis of Table 4 corresponds to tolerable safety level (TSL).

\section{Conclusion}

- Ensuring the safety of the small waterworks in situations such as flood or drought or require the use of appropriate procedures and assessment methods proposed in this paper.

- The proposal to implement risk analysis methods fits into the European Union's approach in assessing the protection of small water supply systems and at the same time provides the necessary information to make decisions in everyday operation.

- Ability to use the presented method in the assessment of various water supply will help in making appropriate decisions by engineers, designers or government officials in selecting methods of consumer protection in the face of undesirable events.

- Small water supply systems should be subjected to centralized control and management what will improve functioning and provide enhanced consumer water safety. 


\section{Literature}

[1] Andreolli M., Giovannini M., Fatone F., Kyamunyogonya M., Yatuha J. A basic bottom-up approach for small systems of safe-water supply: A decentralized case study in Uganda, Journal of Water Supply: Research and Technology - AQUA, 64 (1)2014, pp. 105-116.

[2] Bayraktar B.: Determining optimum hydraulic parameters in branched water supply system. Journal of the Balkan Tribological Association, 2(18)2012, pp. 174-183.

[3] Council Directive 98/83/EC of 3 November 1998 on the quality of water intended for human consumption.

[4] Craun G.F., Calderon R.I. 2001. Waterborne disease outbreaks caused by distribution system deficiencies. Journal AWWA, (1)2001, s. 82-91.

[5] Dzienis L.: Niezawodność wiejskich systemów zaopatrzenia w wodę. Wydawnictwo Politechniki Białostockiej. Rozprawy naukowe nr 4. Białystok 1991.

[6] Haider H., Sadiq R., Tesfamariam S. Performance indicators for small-and medium-sized water supply systems: A review, Environmental Reviews, 22 (1)2014, pp. 1-40.

[7] Hulsmann A. Small systems large problems: A European inventory of small water systems and associated problems. Nieuwegein, Web-based European Knowledge Network on Water (WEKNOW), 2005.

[8] Hunter P.R., De Sylor M.A., Risebro H.L., Nichols G.L., Kay D., Hartemann, P.: Quantitative Microbial Risk Assessment of Cryptosporidiosis and Giardiasis from Very Small Private Water Supplies, Risk Analysis, 31 (2)2011, pp. 228-236.

[9] Kochubovski M.: Water safety in small-scale supplies and new approaches, Journal of Environmental Protection and Ecology, 12 (4 A)2011, pp. 2011-2018.

[10] Kowalski D.: Zarządzanie jakością wody w systemie wodociągowym. Ochrona Środowiska, 3(31)2009, s. 37-40.

[11] Kwietniewski M., Rak J.: Niezawodność infrastruktury wodociągowej i kanalizacyjnej w Polsce. Polska Akademia Nauk. Komitet Inżynierii Lądowej i Wodnej. Instytut Podstawowych Problemów Techniki. Warszawa 2010.

[12] Lambert A., Taylor R.: Water loss guidelines, Water New Zealand 2010.

[13] Pietrucha-Urbanik K.: Assessment model application of water supply system management in crisis situations, Global Nest Journal, 5(16)2014, pp. 893-900. 
Safety problems of small water supply systems

Problemy bezpieczeństwa małych wodociagów

[14] Pietrucha-Urbanik K.: Failure analysis and assessment on the exemplary water supply network. Engineering Failure Analysis, 57/2015, pp. 137-142 (2015) DOI: 10.1016/j.engfailanal.2015.07.036

[15] Pietrucha-Urbanik K.: Failure Prediction in Water Supply System - Current Issues, Theory and Engineering of Complex Systems and Dependability, Advances in Intelligent Systems and Computing, (365)2015, pp. 351-358.

[16] Rak J., Tchórzewska-Cieślak B.: Five-parametric matrix to estimate the risk connected with water supply system operations. Environment Protection Engineering, 32 (2)2006.

[17] Rak J., Tchórzewska-Cieślak B.: Matrycowe metody analizy ryzyka awarii infrastruktury komunalnej. Czasopismo Inżynierii Lądowej, Srodowiska i Architektury. z. 61 (1), 2014, 233-244. DOI: 10.7862/rb.2014.16

[18] Rak R.J., Tchórzewska-Cieślak B.: Metody analizy i oceny ryzyka w systemie zaopatrzenia w wodę, Oficyna Wydawnicza Politechniki Rzeszowskiej, Rzeszów 2005.

[19] Rak J., Tchórzewska-Cieślak B.: Ryzyko w eksploatacji systemów zbiorowego zaopatrzenia w wodę. Wydawnictwo Seidel-Przywecki Sp. z o.o. Rzeszów 2013.

[20] Rozporządzenie Ministra Zdrowia z dnia 29 marca 2007 r. w sprawie jakości wody przeznaczonej do spożycia przez ludzi (Dz. U. Nr 61, poz. 417, z późn. zm.).

[21] Szpak D., Tchórzewska-Cieślak B.: Analiza i ocena zabezpieczenia systemów zbiorowego zaopatrzenia w wodę przed incydentalnym skażeniem. Journal of KONBiN, 2(34)/2015.

[22] Tchórzewska-Cieślak B.: Risk management system in water-pipe network functioning. Proceedings of the European Safety and Reliability Conference 2009, Safety, Reliability and Risk Analysis: Theory, Methods and Application, 3, pp. 2463-2471.

[23] Tchórzewska-Cieślak B.: Metody analizy i oceny ryzyka awarii podsystemu dystrybucji wody. Oficyna Wydawnicza Politechniki Rzeszowskiej, Rzeszów 2011.

[24] Tchórzewska-Cieślak B., Szpak D.: Propozycja metody analizy i oceny bezpieczeństwa dostawy wody. Ochrona Środowiska, 37(3)2015, pp. 43-47.

[25] United Nations Development Programme: Summary human development report 2006. Beyond scarcity: power, poverty and the global water crisis. New York, UNDP, 2006.

[26] USEPA: Distribution system inventory, integrity and water quality, Office of Ground Water and Drinking Water, Total Coliform Rule Issue Paper, Washington DC 2007. 
[27] WB: A Water Scorecard, Public Policy for the Private Sector, The World Bank Group - Private Sector and Infrastructure Network 2002.

[28] World Health Organization: Step-by-step Risk Management for Drinkingwater Suppliers, Geneva 2009.

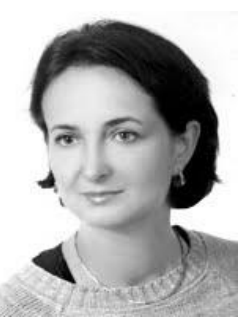

Barbara Tchórzewska-Cieślak is currently working as a professor at Rzeszow University of Technology, Department of Water Supply and Sewage Systems. Specialization - water supply systems, reliability and safety analyses of municipal systems, risk assessment in water supply systems.(Share: $33,33 \%)$.

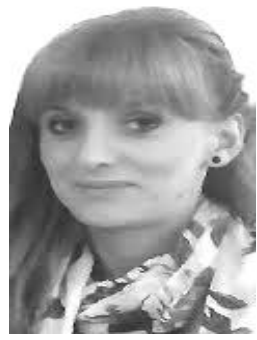

Katarzyna Pietrucha-Urbanik is currently working as an assistant professor at Rzeszow University of Technology, Department of Water Supply and Sewage systems. Specialization - water supply systems, reliability and safety analyses of municipal systems. (Share: 33,33\%).

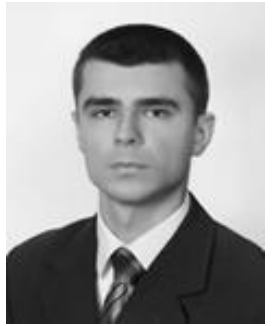

Dawid Szpak is currently working as an assistant at Rzeszow University of Technology, Department of Water Supply and Sewage systems. Specialization - water supply systems, reliability and safety analyses, analysis of undesirable event occurrence in water supply system. (Share: 33,33\%). 
Safety problems of small water supply systems

Problemy bezpieczeństwa małych wodociagów

\section{PROBLEMY BEZPIECZEŃSTWA MAEYCH WODOCIĄGÓW}

\section{Wstęp}

Bezpieczeństwo jest pojęciem odnoszącym się do braku zagrożenia, gwarancji likwidacji lub minimalizacji zagrożeń. W odniesieniu do konsumentów wody do spożycia, rozumiane jest jako prawdopodobieństwo uniknięcia zagrożenia, wynikającego ze spożycia wody o jakości niezgodnej $\mathrm{z}$ obowiązującym normatywem lub jej brakiem $[2,5,6,11,16,23,28]$. Miarą tak rozumianego bezpieczeństwa jest ryzyko funkcjonowania systemu zbiorowego zaopatrzenia w wodę (SZZW). Ujęcia wody dla wiejskich jednostek osadniczych stanowią najczęściej wody podziemne. Są to wody lepszej, jakości niż wody powierzchniowe i nie wymagają skomplikowanych procesów uzdatniania [16]. W wielu przypadkach ulęgają jednak poważnym zanieczyszczeniom, często trudnym do usunięcia, co stanowi poważne zagrożenie dla konsumentów wody. Zagrożenia dla czystości wód podziemnych, niejednokrotnie wynikają z zanieczyszczeń obszarowych związanych $\mathrm{z}$ działalnością rolniczą (nawozy chemiczne, środki ochrony roślin, itp.), a także ze skażenia pięter wodonośnych ściekami bytowo-gospodarczymi w wyniku nieskanalizowania jednostki osadniczej $[4,5]$. Przyczyną zanieczyszczenia ujęć wód podziemnych mogą być również zdarzenia incydentalne takie jak niekontrolowany zrzut ścieków nieoczyszczonych z oczyszczalni, wycieki odcieków ze składowisk odpadów czy wycieki gnojowicy. Niejednokrotnie przyczyna skażenia jest trudna do jednoznacznego ustalenia. Innym problemem, jest tzw. wtórne zanieczyszczenie wody w samej sieci wodociągowej, którego główną przyczyną są niekorzystne warunki hydrauliczne pracy sieci (m.in. niskie prędkości przepływu wody) połączone ze starzejącymi się rurociągami lub niestabilność chemiczna wody [17-19, 22].

Szacuje się, że jeden na dziesięciu mieszkańców Unii Europejskiej korzysta $\mathrm{z}$ małych systemów wodociągowych $\mathrm{w}$ tym $\mathrm{z}$ prywatnych studni [28]. Zgodnie z klasyfikacją podaną przez AWWA za małe systemy wodociągowe uznaje się takie, w których zapotrzebowanie na wodę jest mniejsze niż 20 tys. $\mathrm{m}^{3}$ na dobę [25], natomiast $\mathrm{W}$ pracy [12] Autorzy podają podział $\mathrm{z}$ uwzględnieniem przyłączy wodociągowych (< 2500 przyłączy wodociągowych). Klasyfikacja z uwzględnieniem liczby obsługiwanych mieszkańców pojawia się w opracowaniu m.in. Banku Światowego ( $<125000$ obsługiwanych mieszkańców) [27], jak również Agencji Ochrony Środowiska Stanów Zjednoczonych $(<3300$ obsługiwanych mieszkańców) [26] oraz w Dyrektywie Komisji Unii Europejskiej [3] podającej równocześnie zapotrzebowanie na poziomie mniejszym niż 1 tys. $\mathrm{m}^{3} / \mathrm{d}$ lub systemu obsługującego mniej niż 5 tys. mieszkańców. Podane klasyfikacje różnicuje m.in. gęstość zaludnienia oraz stopień rozwoju danego regionu.

Aktualnym problemem dla zaopatrzenia w wodę małych aglomeracji są ekstremalne zjawiska związane ze zmianami klimatycznymi takie jak powodzie 
a przede wszystkim susze. Niskie stany wód powodują wysychanie studni oraz trudności w poborze wody z ujęć wód powierzchniowych [1,9]. Często istotnym problemem jest zły stan techniczny urządzeń zaopatrujących $\mathrm{w}$ wodę oraz nieprawidłowe rozmieszczenie punktów poboru wody, np. w pobliżu zbiorników asenizacyjnych, co może powodować potencjalne zanieczyszczenia [8]. Na przeszkodzie do poprawy istniejącej sytuacji stoi brak środków finansowych oraz zaplecza technicznego, niewłaściwa eksploatacja systemu, jak również brak świadomości wśród odbiorców wody o istniejącym zagrożeniu [13-15].

Głównym celem pracy jest przedstawienie zagadnienia bezpieczeństwa konsumentów wody w wiejskich jednostkach osadniczych. Praca zawiera podstawowe pojęcia dotyczące bezpieczeństwa konsumentów wody oraz metodę jego analizy na podstawie ryzyka związanego $\mathrm{z}$ funkcjonowaniem wiejskich SZZW

\section{Bezpieczeństwo konsumentów wody}

W wyniku zaistnienia w SZZW różnego rodzaju zdarzeń niepożądanych konsumenci mogą zostać pozbawieni dostępu do bieżącej, zdatnej do spożycia wody przez parę godzin, dób, a nawet tygodni. Przykładem zakłóceń w funkcjonowaniu wodociągów wiejskich są:

- zanieczyszczenie ujęcia wody pestycydami pochodzącymi z nawożenia gruntów rolnych (sołectwa gminy Pikoszów, 01.2012 r.),

- zanieczyszczenie ujęcia wody w wyniku podtopienia (Płoty, 04.2008 r.),

- długotrwały brak opadów, wysokie temperatury, susza hydrologiczna, brak wody w studniach (gm. Błażowa, 07-08.2015 r.),

- znaczne rozproszenie wsi, niewystarczająca wydajność wodociągu, brak inwestycji w zakresie rozbudowy wodociągu (Mokra Wieś, 04.2015 r.),

- niski poziom wody w rzece, susza hydrologiczna (gmina Brzyska, 10.2012 r.),

- zniszczenie rurociągu doprowadzającego wodę ze studni do stacji uzdatniania wody (SUW) w wyniku usunięcia się skarpy przy ujęciu wody powstałego na skutek powodzi (Dąbrówki, 08.2004 r.),

- zanieczyszczenie ujęcia wody chloropiryfosem (pestycyd fotoorganiczny używany m.in. do zwalczania stonki ziemniaczanej), (gm. Pikoszów, 11.2011 r.),

- przedostanie się bakterii grupy coli do ujęcia wody, prawdopodobnie na skutek długotrwałych opadów (Jabłonna, 09.2008 r.),

- wylanie rzeki w pobliżu SUW (Płoty, 04.2008 r.).

Dla potrzeb analizy bezpieczeństwa konsumentów wody wprowadza się pojęcie aktualnego poziomu bezpieczeństwa (APB), który rozumiany jest jako poziom bezpieczeństwa konsumentów wody $\mathrm{w}$ danych warunkach eksploatacyjnych SZZW. Wyróżniono następujące poziomy bezpieczeństwa konsumentów wody:

- tolerowany poziom bezpieczeństwa (TPB) - poziom bezpieczeństwa konsumentów wody, w którym w wyniku eksploatacji SZZW nie istnieją przesłanki do zagrożenia zdrowia lub życia konsumentów wody, 
Safety problems of small water supply systems

Problemy bezpieczeństwa małych wodociagów

- kontrolowany poziom bezpieczeństwa (KPB) - poziom bezpieczeństwa konsumentów wody, w którym w wyniku eksploatacji SZZW może zaistnieć zagrożenie zdrowia konsumentów wody, ale istnieją wystarczające bariery ochronne zabezpieczające konsumentów wody,

- nieakceptowany poziom bezpieczeństwa (NPB) - poziom bezpieczeństwa konsumentów wody, po przekroczeniu którego konsumenci narażeni są na utratę zdrowia lub życia.

$\mathrm{Na}$ rysunku 1 przedstawiono procedurę działań związanych $\mathrm{z}$ funkcjonowaniem małych wodociągów w aspekcie zapewnienia ich bezpieczeństwa [10, 19, 22-24].

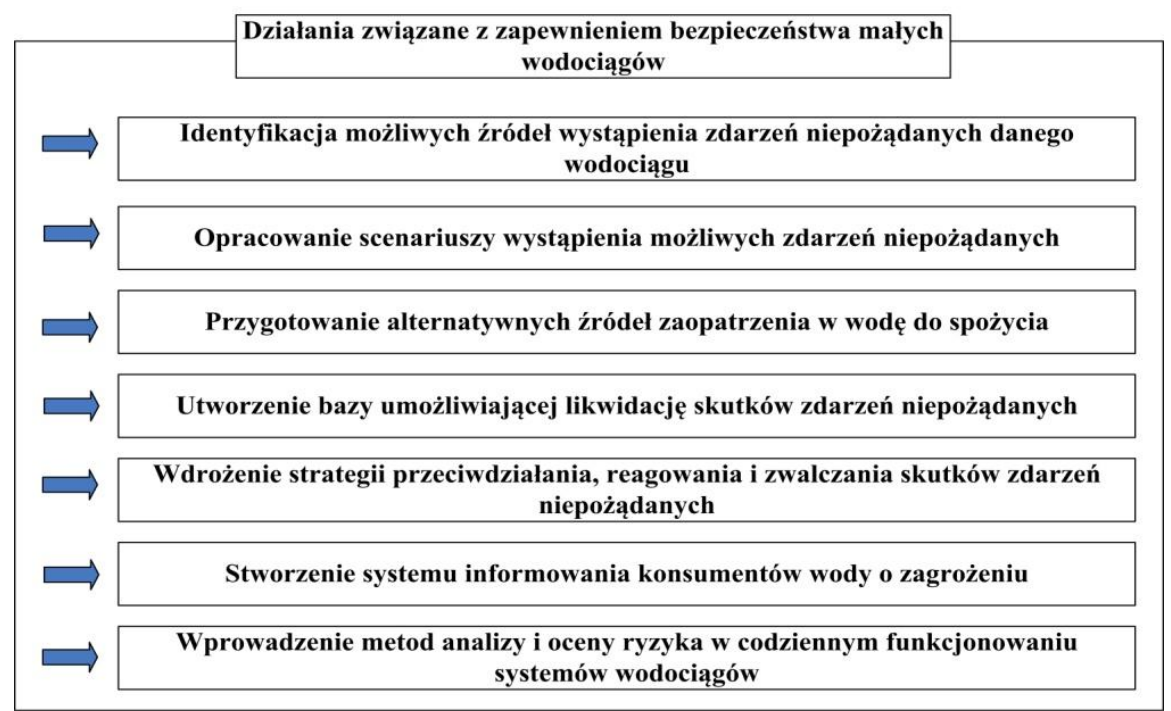

Rys. 1. Działania zapewniające ciagłość funkcjonowania małych wodociagów

W celu analizy bezpieczeństwa konsumentów wody konieczne jest zdefiniowanie stanów eksploatacyjnych SZZW. Wyróżniono następujące stany eksploatacyjne SZZW, uwzględniające nominalną wydajność produkcji wody $\left(Q_{d n}\right)$ oraz maksymalne dobowe zapotrzebowanie na wodę w ciągu roku $\left(Q_{d \max }\right)$ :

- stan zdatności - stan SZZW, który charakteryzuje się pracą bezuszkodzeniową. System wykonuje swoje zadanie zgodnie z obowiązującymi unormowaniami prawnymi i oczekiwaniami konsumentów wody, w zakresie ilości wody do spożycia tj. nominalnej wydajności produkcji wody $Q_{d n} \geq 0,7 Q_{d \max }$ i jakości: woda do spożycia spełnia wymagania obowiązującego Rozporządzenia [20]. System zbiorowego zaopatrzenia w wodę nie stwarza zagrożenia dla zdrowia i życia konsumentów wody.

- stan ograniczonej zdatności - stan SZZW, który charakteryzuje się krótkotrwałymi zakłóceniami w pracy: 0,3 $Q_{d \max } \leq Q_{d n}<0,7 Q_{d \max }$ lub występują przerwy w dostawie wody do $24 \mathrm{~h}$, istnieje możliwość eskalacji zdarzeń 
niepożądanych (powstania tzw. efektu domina). Jeżeli woda nie stwarza zagrożenia dla zdrowia konsumentów, możliwe jest przekroczenie dopuszczalnych wartości parametrów określonych w załącznikach nr 3 i nr 4 do Rozporządzenia [20]. W przypadku gdy można usunąć zanieczyszczenie w ciągu 30 dób, to właściwy inspektor sanitarny stwierdza przydatność wody do spożycia na warunkach tzw. przyznanego odstępstwa [20],

- stan utraty zdatności - stan SZZW, w którym system działa niesprawnie lub przestaje działać, $0<Q_{d n}<0,3 Q_{d \max }$ lub występują przerwy w dostawie wody $>24 \mathrm{~h}$. Konsumenci narażeni są na spożycie wody o nieodpowiedniej jakości.

- stan klęski - stan SZZW, w którym system przestaje działać, a konsumenci pozbawieni są dostępu do wody zdatnej do picia. Brak ochrony konsumentów wody przed zagrożeniami (np. w wyniku powodzi, suszy hydrologicznej).

\section{Metoda oceny bezpieczeństwa konsumentów wody na podstawie analizy ryzyka}

W wyniku zaistnienia w SZZW tzw. reprezentatywnego scenariusza awaryjnego (RSA), konsumenci wody narażeni są na możliwość utraty bezpieczeństwa. Miarą utraty bezpieczeństwa konsumentów wody do spożycia jest ryzyko związane z możliwością spożycia wody o nieodpowiedniej jakości lub jej brakiem $[6,7$, 16-19]. Ryzyko jest funkcją trzech parametrów $r=f(P, C, O)$. Parametry $P$ oraz $C$ są wprost proporcjonalne do wartości ryzyka, natomiast parametr $O$ jest odwrotnie proporcjonalny do wartości ryzyka [16-19]. Przyjęte założenie znalazło swoje uzasadnienie i jest celowe, ze względu na odwrotnie proporcjonalny charakter przyjętego parametru ochrony, który ma znaczący wpływ na redukcję ryzyka, min. poprzez stosowanie systemu wczesnego ostrzegania. Wprowadzenie znaczącej ochrony może prowadzić do minimalizacji ryzyka pojawiających się zdarzeń niepożądanych $\mathrm{w}$ systemach zaopatrzenia $\mathrm{w}$ wodę. Metoda ta znalazła zastosowanie w praktyce wodociągowej ze względu na specyfikę tego systemu, jak również zmodyfikowana jest rekomendowana przez WHO w ocenie planów bezpieczeństwa wodnego (PBW).

Ryzyko konsumenta wody $r_{k}$ wyznacza się wg autorskiej metody prof. J. Raka [18]:

$$
r_{k}=\frac{P_{S i} \cdot C_{S i}}{O_{S i}}
$$

$P_{S i}-$ prawdopodobieństwo wystąpienia $i$-tego RSA,

$C_{S i}$ - waga punktowa związana z możliwymi skutkami dla konsumentów wody w wyniku zaistnienia $i$-tego RSA,

$O_{S i}$ - waga punktowa związana z ochroną konsumentów wody przed $i$-tym RSA.

Każdorazowo dla parametrów $P_{S i}, C_{S i}$ i $O_{S i}$ przyjmuje się poziom wielkości za pomocą skali punktowej od 1 do 5 wykorzystując metodę matrycową w postaci trójparametrycznej opisaną szczegółowo w pracach [16, 18, 19, 23]. Ryzyko przyjmuje wartości z zakresu [0,20-25]. 
Safety problems of small water supply systems Problemy bezpieczeństwa matych wodociagów

W tabelach 1-3 zaproponowano przyjęcie następującej skali oraz wag punktowych dla poszczególnych parametrów.

Tabela 1. Kryteria $i$ wagi punktowe dla parametru P [19,23]

\begin{tabular}{|c|l|c|}
\hline Prawdopodobieństwo & \multicolumn{1}{|c|}{ Opis parametru P } & $\begin{array}{c}\text { Waga } \\
\text { punktowa }\end{array}$ \\
\hline bardzo małe & raz na 10 lat lub rzadziej & 1 \\
\hline małe & raz na 5 - 10 lat & 2 \\
\hline przeciętne & raz na 1 - 5 lat & 3 \\
\hline duże & $1-12$ razy w roku & 4 \\
\hline bardzo duże & częściej niż raz w miesiącu & 5 \\
\hline
\end{tabular}

Tabela 2. Kryteria i wagi punktowe dla parametru C [19, 21, 23]

\begin{tabular}{|c|c|c|}
\hline Skutki & Opis parametru $C$ & $\begin{array}{c}\text { Waga } \\
\text { punktowa }\end{array}$ \\
\hline $\begin{array}{c}\text { bardzo } \\
\text { małe }\end{array}$ & $\begin{array}{l}\text { - nieznaczne pogorszenie parametrów organoleptycznych wody } \\
\text { niestanowiące zagrożenia dla konsumentów, } \\
\text { - lokalne obniżenie ciśnienia w sieci wodociągowej, }\end{array}$ & 1 \\
\hline make & $\begin{array}{l}\text { - } \text { znaczące pogorszenie parametrów organoleptycznych wody } \\
\text { stanowiące uciazżliwość dla konsumentów, } \\
\text { - } \text { brak zagrożenia zdrowotnego, } \\
\text { - } \text { pojedyncze skargi konsumentów wody, } \\
\text { - } \\
\text { spadek dobowej produkcji wody do wartości } 70 \% \mathrm{Q}_{\operatorname{maxd}} \text { lub } \\
\text { przerwy w dostawie wody do } 2 \mathrm{~h} \\
\text { - } \\
\text { obniżenie ciśnienia w sieci wodociągowej, }\end{array}$ & 2 \\
\hline przeciętne & $\begin{array}{ll}- & \text { znaczna uciążliwość organoleptyczna wody (duża mętność, } \\
& \text { odór), } \\
- & \text { przekroczenie parametrów fizykochemicznych, } \\
- & \text { zagrożenie dla zdrowia konsumentów, } \\
- & \text { pojedyncze niedyspozycje zdrowotne konsumentów związane } \\
& \text { ze spożyciem zanieczyszczonej wody, } \\
- & \text { spadek dobowej produkcji wody do wartości } 0,5 Q_{d \max } \leq Q_{d n}< \\
& 0,7 Q_{d m a x} \text { lub lokalne przerwy w dostawie wody od } 2 \text { do } 12 \mathrm{~h}, \\
- & \text { obniżenie ciśnienia w sieci wodociągowej, }\end{array}$ & 3 \\
\hline duże & $\begin{array}{l}\text { przekroczenia parametrów fizykochemicznych oraz } \\
\text { bakteriologicznych, } \\
\text { - } \text { wtórne zanieczyszczenie wody w poszczególnych } \\
\text { fragmentach sieci wodociągowej, } \\
\text { - liczne zatrucia konsumentów związane ze spożyciem } \\
\text { zanieczyszczonej wody, } \\
\text { - } \\
\text { komunikaty w mediach lokalnych informujące o } \\
\text { zanieczyszczeniu wody przeznaczonej do spożycia, } \\
\text { - } \text { spadek dobowej produkcji wody do wartości } 0,3 Q_{d \max } \leq Q_{d n}< \\
0,5 Q_{d m a x} \text { lub lokalne przerwy w dostawie wody od } 12 \text { do } 24 \\
\text { h, } \\
\text { obniżenie ciśnienia w sieci wodociagowei. }\end{array}$ & 4 \\
\hline
\end{tabular}


Tabela 2. Kryteria i wagi punktowe dla parametru C [19, 21, 23] (cd)

\begin{tabular}{|c|c|c|}
\hline $\begin{array}{c}\text { bardzo } \\
\text { duże }\end{array}$ & $\begin{array}{l}\text { - } \text { rozległe zanieczyszczenie bakteriologiczne wody, obecność } \\
\text { mikroorganizmów chorobotwórczych, przekroczenie } \\
\text { parametrów fizykochemicznych, } \\
\text { - } \text { wtórne zanieczyszczenie wody w sieci wodociągowej, } \\
\text { - } \text { masowe zatrucia, konieczność hospitalizacji } \\
\text { poszkodowanych osób, } \\
\text { - } \text { komunikaty w mediach ogólnokrajowych informujące o } \\
\text { zanieczyszczeniu wody przeznaczonej do spożycia, } \\
\text { - } \text { konieczność zaangażowania profesjonalnych służb } \\
\text { ratowniczych: m. in. Państwowej Straży Pożarnej, } \\
\text { Państwowego Ratownictwa Medycznego, } \\
\text { - } \quad \text { spadek dobowej produkcji wody do wartości } Q_{d n}<0,3 \\
Q_{d m a x} \\
\text { - przerwy w dostawie wody zdatnej do spożycia powyżej } 24 \\
\text { h, } \\
\text { - awaria głównych urządzeń SUW lub pompowni } \\
\text { wodociągowych, } \\
\text { - awaria głównych przewodów wodociągowych zasilających } \\
\text { miasto/gmine. }\end{array}$ & 5 \\
\hline
\end{tabular}

Tabela 3. Kryteria $i$ wagi punktowe dla parametru $O[19,23]$

\begin{tabular}{|c|c|c|}
\hline Ochrona & Opis parametru $O$ & $\begin{array}{c}\text { Waga } \\
\text { punktowa }\end{array}$ \\
\hline $\begin{array}{c}\text { bardzo } \\
\text { niska }\end{array}$ & 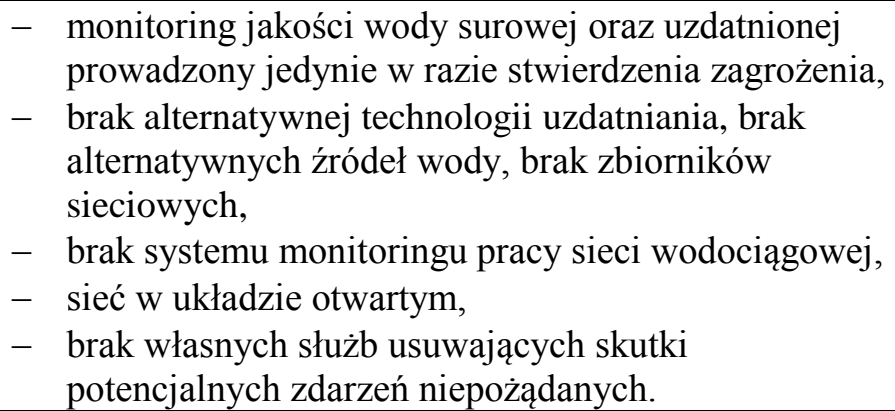 & -1 \\
\hline niska & 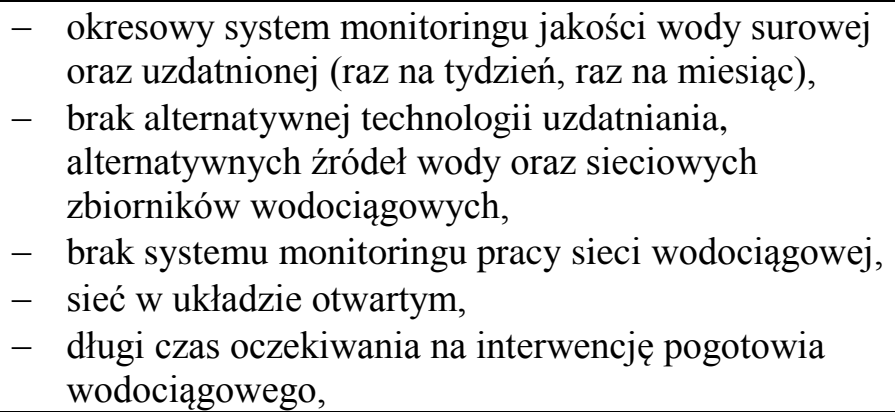 & -2 \\
\hline
\end{tabular}


Safety problems of small water supply systems Problemy bezpieczeństwa małych wodociagów

Tabela 3. Kryteria $i$ wagi punktowe dla parametru $O[19,23](\mathrm{cd})$

\begin{tabular}{|c|c|c|}
\hline przeciętna & $\begin{array}{l}\text { - } \\
\text { standardowy system monitoringu jakości wody } \\
\text { surowej oraz uzdatnionej, } \\
\text { - } \text { brak alternatywnej technologii uzdatniania, } \\
\text { alternatywnych źródeł wody oraz sieciowych } \\
\text { zbiorników wodociągowych, } \\
\text { - } \\
\text { standardowy system monitoringu pracy sieci } \\
\text { wodociągowej, } \\
\text { - } \\
\text { sieć w układzie otwartym, brak możliwości odcięcia } \\
\text { uszkodzonego przewodu bez przerw w dostawie } \\
\text { wody, } \\
\text { - } \\
\text { długi czas oczekiwania na interwencję pogotowia } \\
\text { wodociągowego, }\end{array}$ & 3 \\
\hline wysoka & $\begin{array}{ll}\text { - } & \text { standardowy system monitoringu jakości wody } \\
& \text { surowej oraz uzdatnionej (pobór prób wody kilka razy } \\
& \text { w ciągu doby), } \\
\text { - } & \text { brak alternatywnej technologii uzdatniania, } \\
\text { - } & \text { możliwość wykorzystania alternatywnych źródeł wody } \\
& \text { lub wody zgromadzonej w sieciowych zbiornikach } \\
& \text { wodociągowych, } \\
\text { - } & \text { standardowy system monitoringu pracy sieci } \\
& \text { wodociągowej (pomiar ciśnienia i natężenia } \\
\text { przepływu na głównych obiektach wodociągowych), } \\
\text { - } & \text { sieć w układzie mieszanym, }\end{array}$ & 4 \\
\hline $\begin{array}{l}\text { bardzo } \\
\text { wysoka }\end{array}$ & $\begin{array}{ll}\text { - } & \text { kompleksowy system monitoringu jakości wody } \\
\text { surowej oraz uzdatnionej z funkcją alarm, } \\
\text { - } & \text { możliwość wykorzystania alternatywnej technologii } \\
& \text { uzdatniania, alternatywnych źródeł wody, wody } \\
\text { zgromadzonej w sieciowych zbiornikach } \\
\text { wodociągowych, } \\
\text { - } & \text { kompleksowy system monitoringu pracy sieci } \\
& \text { wodociągowej, wykorzystanie oprogramowania } \\
& \text { SCADA oraz GIS, } \\
- & \text { sieć w układzie zamkniętym, możliwość odcięcia } \\
& \text { uszkodzonego przewodu, } \\
- & \text { rezerwowanie strategicznych obiektów na SUW lub } \\
& \text { w pompowni wodociągowej, } \\
- & \text { sprawnie działające pogotowie wodociągowe. }\end{array}$ & 5 \\
\hline
\end{tabular}


Ocena bezpieczeństwa polega na porównaniu otrzymanej wartości ryzyka z przyjętą skalą. Przy określaniu kryteriów do oceny bezpieczeństwa konsumentów wody, zaprezentowano podejście eksperckie do analizy ryzyka uwzględniające wartości kryterialne odpowiednich poziomów ryzyka, które zostały przyjęte na podstawie analizy danych eksploatacyjnych oraz opinii i informacji uzyskanych od ekspertów z przedsiębiorstw wodociągowych. W ocenie ekspertów wykorzystano analizę zdarzeń niepożądanych o podobnym charakterze.

W tabeli 4 zaproponowano kryteria dla oceny bezpieczeństwa konsumentów wody.

Tabela 4. Poziom bezpieczeństwa konsumentów wody

\begin{tabular}{|c|c|}
\hline $\begin{array}{c}\text { Wartość wyznaczonego } \\
\text { ryzyka }\end{array}$ & $\begin{array}{c}\text { Poziom bezpieczeństwa } \\
\text { konsumentów wody }\end{array}$ \\
\hline $0,20 \leq \mathrm{r}_{\mathrm{T}} \leq 5,0$ & TPB \\
\hline $5,0<\mathrm{r}_{\mathrm{K}} \leq 9,0$ & $\mathrm{KPB}$ \\
\hline $9,0<\mathrm{r}_{\mathrm{N}} \leq 25,0$ & $\mathrm{NPB}$ \\
\hline
\end{tabular}

Opracowana metoda została przedstawiona na przykładzie aplikacyjnym:

- w wodzie przeznaczonej do spożycia odnotowano znaczące pogorszenie parametrów organoleptycznych; $C=2$,

- pogorszenie parametrów organoleptycznych wody przeznaczonej do spożycia odnotowywane jest przez przedsiębiorstwo wodociągowe kilka razy w roku; $P=4$,

- system wodociągowy wyposażony jest $\mathrm{w}$ standardowy system monitoringu jakości wody, istnieje możliwość wykorzystania alternatywnych źródeł wody lub wody zgromadzonej $\mathrm{w}$ sieciowych zbiornikach wodociągowych w przypadku wystąpienia sytuacji kryzysowej; $O=4$.

Na podstawie powyższych informacji wyznaczono wartość ryzyka $r=2$, co na podstawie tabeli 4 odpowiada tolerowanemu poziomowi bezpieczeństwa (TPB).

\section{Podsumowanie}

- Zapewnienie bezpieczeństwa funkcjonowania małych wodociągów w sytuacjach takich jak powódź, bądź susza wymaga stosowania odpowiednich procedur i metod oceny zaproponowanych w niniejszej pracy.

- Propozycja implementacji metod analizy ryzyka wpisuje się w podejście Unii Europejskiej w ocenie ochrony małych wodociągów, równocześnie dostarczy informacji niezbędnych do podejmowania decyzji w codziennej eksploatacji.

- Możliwość zastosowania zaprezentowanej metody w ocenie różnych wodociągów pomoże w podejmowaniu odpowiednich decyzji przez inżynierów, projektantów, bądź urzędników państwowych w wyborze metod ochrony konsumentów w obliczu zdarzeń niepożądanych. 
Safety problems of small water supply systems

Problemy bezpieczeństwa małych wodociagów

- Małe systemy wodociągowe powinny podlegać scentralizowanej kontroli i zarządzaniu, co poprawi ich funkcjonowanie oraz zapewni zwiększenie poziomu bezpieczeństwa konsumentów wody.

\section{Literatura}

[1] Andreolli M., Giovannini M., Fatone F., Kyamunyogonya M., Yatuha J. A basic bottom-up approach for small systems of safe-water supply: A decentralized case study in Uganda, Journal of Water Supply: Research and Technology - AQUA, 64 (1)2014, pp. 105-116.

[2] Bayraktar B.: Determining optimum hydraulic parameters in branched water supply system. Journal of the Balkan Tribological Association, 2(18)2012, pp. 174-183.

[3] Council Directive 98/83/EC of 3 November 1998 on the quality of water intended for human consumption.

[4] Craun G.F., Calderon R.I. 2001. Waterborne disease outbreaks caused by distribution system deficiencies. Journal AWWA, (1)2001, s. 82-91.

[5] Dzienis L.: Niezawodność wiejskich systemów zaopatrzenia w wodę. Wydawnictwo Politechniki Białostockiej. Rozprawy naukowe nr 4. Białystok 1991.

[6] Haider H., Sadiq R., Tesfamariam S. Performance indicators for small-and medium-sized water supply systems: A review, Environmental Reviews, 22 (1)2014, pp. 1-40.

[7] Hulsmann A. Small systems large problems: A European inventory of small water systems and associated problems. Nieuwegein, Web-based European Knowledge Network on Water (WEKNOW), 2005.

[8] Hunter P.R., De Sylor M.A., Risebro H.L., Nichols G.L., Kay D., Hartemann, P.: Quantitative Microbial Risk Assessment of Cryptosporidiosis and Giardiasis from Very Small Private Water Supplies, Risk Analysis, 31 (2) 2011, pp. 228-236.

[9] Kochubovski M.: Water safety in small-scale supplies and new approaches, Journal of Environmental Protection and Ecology, 12 (4 A)2011, pp. 20112018.

[10] Kowalski D.: Zarządzanie jakością wody w systemie wodociągowym. Ochrona Środowiska, 3(31)2009, s. 37-40.

[11] Kwietniewski M., Rak J.: Niezawodność infrastruktury wodociągowej i kanalizacyjnej w Polsce. Polska Akademia Nauk. Komitet Inżynierii Lądowej i Wodnej. Instytut Podstawowych Problemów Techniki. Warszawa 2010.

[12] Lambert A., Taylor R.: Water loss guidelines, Water New Zealand 2010. 
[13] Pietrucha-Urbanik K.: Assessment model application of water supply system management in crisis situations, Global Nest Journal, 5(16)2014, pp. 893-900.

[14] Pietrucha-Urbanik K.: Failure analysis and assessment on the exemplary water supply network. Engineering Failure Analysis, 57/2015, pp. 137-142 (2015) DOI: 10.1016/j.engfailanal.2015.07.036

[15] Pietrucha-Urbanik K.: Failure Prediction in Water Supply System - Current Issues, Theory and Engineering of Complex Systems and Dependability, Advances in Intelligent Systems and Computing, (365)2015, pp. 351-358.

[16] Rak J., Tchórzewska-Cieślak B.: Five-parametric matrix to estimate the risk connected with water supply system operations. Environment Protection Engineering, 32 (2)2006.

[17] Rak J., Tchórzewska-Cieślak B.: Matrycowe metody analizy ryzyka awarii infrastruktury komunalnej. Czasopismo Inżynierii Lądowej, Srodowiska i Architektury. z. 61 (1), 2014, 233-244. DOI: 10.7862/rb.2014.16

[18]Rak R.J., Tchórzewska-Cieślak B.: Metody analizy i oceny ryzyka w systemie zaopatrzenia w wodę, Oficyna Wydawnicza Politechniki Rzeszowskiej, Rzeszów 2005.

[19] Rak J., Tchórzewska-Cieślak B.: Ryzyko w eksploatacji systemów zbiorowego zaopatrzenia w wodę. Wydawnictwo Seidel-Przywecki Sp. z o.o. Rzeszów 2013.

[20] Rozporządzenie Ministra Zdrowia z dnia 29 marca 2007 r. w sprawie jakości wody przeznaczonej do spożycia przez ludzi (Dz. U. Nr 61, poz. 417, z późn. $\mathrm{zm}$.).

[21] Szpak D., Tchórzewska-Cieślak B.: Analiza i ocena zabezpieczenia systemów zbiorowego zaopatrzenia $\mathrm{w}$ wodę przed incydentalnym skażeniem. Journal of KONBiN, 2(34)/2015.

[22] Tchórzewska-Cieślak B.: Risk management system in water-pipe network functioning. Proceedings of the European Safety and Reliability Conference 2009, Safety, Reliability and Risk Analysis: Theory, Methods and Application, 3, pp. 2463-2471.

[23] Tchórzewska-Cieślak B.: Metody analizy i oceny ryzyka awarii podsystemu dystrybucji wody. Oficyna Wydawnicza Politechniki Rzeszowskiej, Rzeszów 2011.

[24] Tchórzewska-Cieślak B., Szpak D.: Propozycja metody analizy i oceny bezpieczeństwa dostawy wody. Ochrona Środowiska, 37(3)2015, pp. 43-47.

[25] United Nations Development Programme: Summary human development report 2006. Beyond scarcity: power, poverty and the global water crisis. New York, UNDP, 2006. 
Safety problems of small water supply systems Problemy bezpieczeństwa małych wodociagów

[26] USEPA: Distribution system inventory, integrity and water quality, Office of Ground Water and Drinking Water, Total Coliform Rule Issue Paper, Washington DC 2007.

[27] WB: A Water Scorecard, Public Policy for the Private Sector, The World Bank Group - Private Sector and Infrastructure Network 2002.

[28] World Health Organization: Step-by-step Risk Management for Drinkingwater Suppliers, Geneva 2009.

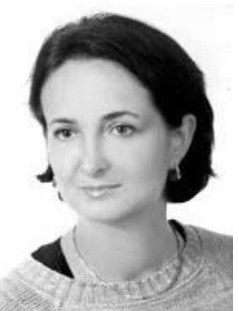

Dr hab. inż. Barbara Tchórzewska-Cieślak, prof. PRz pracuje na stanowisku profesora nadzwyczajnego $w$ Zaktadzie Zaopatrzenia $w$ Wode i Odprowadzania Ścieków Politechniki Rzeszowskiej. Zainteresowania naukowe: systemy zaopatrzenia $w$ wodę, niezawodność i bezpieczeństwo systemów inżynierskich, niekonwencjonalne metody analizy i oceny ryzyka.

(Udziat 33,33\%)

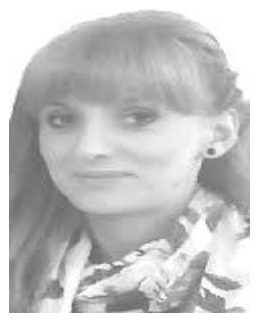

Dr inz. Katarzyna Pietrucha-Urbanik pracuje na stanowisku adiunkta w Zakładzie Zaopatrzenia w Wodę $i$ Odprowadzania Ścieków Politechniki Rzeszowskiej. Specjalizacja: systemy wodociagowe, niezawodność i bezpieczeństwo systemów komunalnych. (Udziat 33,33\%)

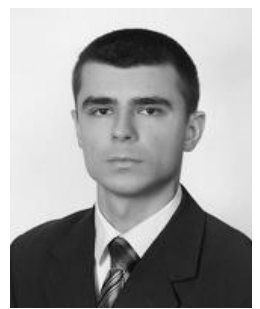

Mgr inz. Dawid Szpak pracuje na stanowisku asystenta w Zaktadzie Zaopatrzenia w Wodę i Odprowadzania Ścieków Politechniki Rzeszowskiej. Zainteresowania naukowe: niezawodność $i$ bezpieczeństwo systemów zaopatrzenia $w$ wodę, zdarzenia incydentalne $w$ systemach zaopatrzenia $w$ wodę. (Udziat 33,33\%) 